\title{
Naphthalene Ring-Fused 2-Aminotryptanthrin as a Fluorescent Chemosensor for $\mathrm{Al}^{3+}$
}

\author{
Jun Kawakami $^{1 *}$, Akihiro Tsuiki ${ }^{1}$, Shunji Ito ${ }^{1}$, and Haruo Kitahara ${ }^{2}$ \\ 1 Graduate School of Science and Technology, Hirosaki University, 3 Bunkyo-cho, Hirosaki, Aomori 036-8561, Japan \\ 2 Kitahara Laboratory Co. Ltd, 3 Bunkyo-cho, Hirosaki, Aomori 036-8561, Japan \\ * Corresponding author: Fax: 81-172-39-3541, and/or e-mail: jun@hirosaki-u.ac.jp
}

\begin{abstract}
Naphthalene ring-fused 2-aminotryptanthrin (Naph-T2NH $\mathbf{N H}_{2}$ ) was synthesized as a fluorescent chemosensor for $\mathrm{Al}^{3+}$. We investigated the metal-ion recognition of $\mathbf{N a p h - T 2 N H}$ through individual addition of $\mathrm{Mg}^{2+}, \mathrm{Ca}^{2+}, \mathrm{Ba}^{2+}, \mathrm{Fe}^{2+}, \mathrm{Fe}^{3+}, \mathrm{Co}^{2+}, \mathrm{Ni}^{2+}, \mathrm{Cu}^{2+}, \mathrm{Ag}^{+}, \mathrm{Zn}^{2+}, \mathrm{Cd}^{2+}, \mathrm{Hg}^{2+}, \mathrm{Al}^{3+}$, and $\mathrm{Pb}^{2+}$ in an acetonitrile solution. When $\mathrm{Mg}^{2+}, \mathrm{Ca}^{2+}, \mathrm{Ba}^{2+}, \mathrm{Co}^{2+}, \mathrm{Ag}^{+}, \mathrm{Zn}^{2+}$, and $\mathrm{Cd}^{2+}$ were individually added to the solution, the shape and intensity of the fluorescence spectra did not change. Conversely, when $\mathrm{Fe}^{2+}, \mathrm{Fe}^{3+}, \mathrm{Ni}^{2+}, \mathrm{Cu}^{2+}, \mathrm{Hg}^{2+}$, and $\mathrm{Pb}^{2+}$ were individually added to the solution, the fluorescence at $604 \mathrm{~nm}$ was quenched. However, the fluorescence at $494 \mathrm{~nm}$ increased significantly upon addition of $\mathrm{Al}^{3+}$. Thus, Naph-T2NH2 is well suited for use as a fluorescent chemosensor for $\mathrm{Al}^{3+}$.
\end{abstract}

Key words: aluminum ion, 2-aminotryptanthrin, fluorescent dye, fluorescent chemosensor

\section{INTRODUCTION}

Tryptanthrin (T, Fig. 1a) is a weakly basic alkaloid formed in a number of plant species [1] that exhibits antimicrobial activity against various pathogenic bacteria and fungi [2]. Upon synthesizing tryptanthrin derivatives as antimicrobial agents [3], some were found to be fluorescent. We have previously shown that 2-aminotryptanthrin ( $\mathbf{T} 2 \mathbf{N H}_{2}$, Fig. 1b) has excellent photophysical properties such as a wide wavelength absorption and emission in the visible region, as well as a high fluorescence quantum yield ( $\left.\Phi_{\mathrm{f}}\right)$ [4]. The fluorescence spectra of $\mathbf{T} \mathbf{2} \mathbf{N H}_{\mathbf{2}}$ in various polarity solvents demonstrated large, positive fluorescent solvatochromism, indicating that $\mathbf{T} \mathbf{2} \mathbf{N H}_{2}$ exhibits a longer fluorescence wavelength in highly polar solvents compared to nonpolar solvents [5]. $\mathbf{T} 2 \mathbf{N H}_{\mathbf{2}}$ and its derivatives have widespread potential applications in diverse fields, such as labeling reagents, chemosensors, laser dyes, photosensitizers, and fluorescent organic devices [6]. As such, it is necessary for these dyes to absorb and emit at long wavelengths. For example, fluorescent dyes that emit at long wavelengths are desirable for applications in biological systems as they reduce auto-fluorescence and photodamage to living cells [7]. Therefore, we propose to shift the absorption maxima $\left(\lambda_{\mathrm{a}, \max }\right)$ and the emission maxima $\left(\lambda_{\mathrm{f}, \max }\right)$ of $\mathbf{T} \mathbf{2} \mathbf{N H}_{\mathbf{2}}$ to longer wavelengths by expanding the $\pi$-conjugation of the aromatic rings. We synthesized naphthalene ring-fused 2-aminotryptanthrin (Naph-T2NH2, Fig. 1c) and investigated the metal ion recognition of Naph-T2NH2 through the individual addition of $\mathrm{Mg}^{2+}, \mathrm{Ca}^{2+}, \mathrm{Ba}^{2+}, \mathrm{Fe}^{2+}, \mathrm{Fe}^{3+}, \mathrm{Co}^{2+}, \mathrm{Ni}^{2+}, \mathrm{Cu}^{2+}$, $\mathrm{Ag}^{+}, \mathrm{Zn}^{2+}, \mathrm{Cd}^{2+}, \mathrm{Hg}^{2+}, \mathrm{Al}^{3+}$, and $\mathrm{Pb}^{2+}$ in an acetonitrile solution.

\section{EXPERIMENTAL}

\subsection{Measurements}

Stock solutions of $\mathbf{N a p h - T 2} \mathbf{N H}_{2}$ were prepared by dissolving appropriate amounts of Naph-T2NH in acetonitrile. Titrations of Naph-T2 $\mathbf{N H}_{2}\left(\left[\mathbf{N a p h}-\mathbf{T} \mathbf{2} \mathbf{N H}_{2}\right]=\right.$ (a)

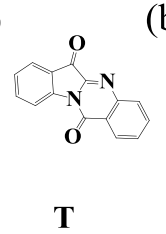

(b)

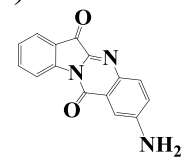

(c)

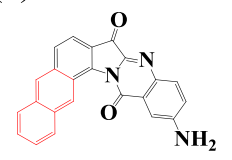

$\mathrm{T}_{2} \mathrm{NH}_{2} \quad$ Naph-T2NH

Figure 1 Structures of (a) tryptanthrin (T), (b) 2aminotryptanthrin $\left(\mathbf{T} 2 \mathbf{N H}_{2}\right.$ ), and (c) naphthalene ring-fused 2-aminotryptanthrin (Naph-T2NH2).

$10 \mu \mathrm{M}, \mathrm{M}=\mathrm{mol} \mathrm{dm}^{-3}$ ) against metal ion solutions were performed in a spectrophotometric cell with a path length of $1 \mathrm{~cm}$. UV-vis spectra (between 200 and $800 \mathrm{~nm}$ ) of the resulting solutions were recorded at room temperature with a JASCO V-670 spectrophotometer after individual additions of each of the 14 metal salts: $\mathrm{Mg}\left(\mathrm{ClO}_{4}\right)_{2}$, $\mathrm{Ca}\left(\mathrm{ClO}_{4}\right)_{2}, \mathrm{Ba}\left(\mathrm{ClO}_{4}\right)_{2}, \mathrm{Fe}\left(\mathrm{ClO}_{4}\right)_{2}, \mathrm{Fe}\left(\mathrm{ClO}_{4}\right)_{3}, \mathrm{Co}\left(\mathrm{ClO}_{4}\right)_{2}$, $\mathrm{Ni}\left(\mathrm{ClO}_{4}\right)_{2}, \mathrm{Cu}\left(\mathrm{ClO}_{4}\right)_{2}, \mathrm{AgClO}_{4}, \mathrm{Zn}\left(\mathrm{ClO}_{4}\right)_{2}, \mathrm{Cd}\left(\mathrm{ClO}_{4}\right)_{2}$, $\mathrm{Hg}\left(\mathrm{ClO}_{4}\right)_{2}, \mathrm{Al}\left(\mathrm{ClO}_{4}\right)_{3}$, and $\mathrm{Pb}\left(\mathrm{ClO}_{4}\right)_{2}$. Fluorescence spectra were measured between 300 and $900 \mathrm{~nm}$ with a Hitachi F4500 fluorometer using the $\lambda_{\mathrm{a} \text {, max }}$ or the isosbestic point as the excitation wavelength $\left(\lambda_{\mathrm{ex}}\right)$. The titrations were performed with metal ions $(10-10000 \mu \mathrm{M})$ as the titrant and Naph-T2 $\mathbf{N H}_{2}(10 \mu \mathrm{M})$ as the titrate. The metal ion sources were identical to those used for the UV-vis studies. Proton nuclear magnetic resonance $\left({ }^{1} \mathrm{H}\right.$ NMR) spectra were recorded on a JEOL JNM-ECA 500 spectrometer in dimethyl sulfoxide (DMSO- $d_{6}$ ) with tetramethylsilane as the internal standard. High-resolution mass spectra (HRMS) were obtained using electrospray ionization (ESI) with a HITACHI NanoFrontier LD spectrometer.

\subsection{Synthesis}

Naph-T2NH 2 was prepared using the procedure shown in Scheme 1. A solution of diethyl ketomalonate hydrate $(0.88$ $\mathrm{g}, 5.8 \mathrm{mmol})$ in acetic acid $(\mathrm{AcOH}, 1.5 \mathrm{~mL})$ was 


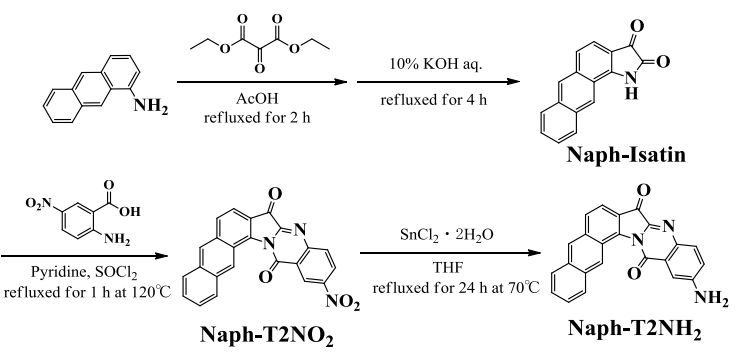

Scheme 1 Synthesis of Naph-T2 $\mathbf{N H}_{2}$.

added over 45 min with stirring to a refluxing solution of 1 aminoanthracene $(0.56 \mathrm{~g}, 2.9 \mathrm{mmol})$ in $\mathrm{AcOH}(9 \mathrm{~mL})$. After addition, the reaction was refluxed for an additional $1.5 \mathrm{~h}$. The $\mathrm{AcOH}$ was then removed in vacuo, and $10 \%$ aqueous $\mathrm{KOH}(30 \mathrm{~mL})$ was added to the residue. The solution was stirred vigorously while refluxing for $4 \mathrm{~h}$. After cooling, the solution was filtered to remove the small amount of solid material and carefully (due to evolution of $\mathrm{CO}_{2}$ ) acidified it with $35 \% \mathrm{HCl}$ to $\mathrm{pH} 1.0$. The purple-red precipitate was filtered, washed with $n$-hexane, and dried to afford naphthalene ring-fused isatin (Naph-Isatin). Recrystallization in dichloromethane afford pure NaphIsatin $(0.21 \mathrm{~g}, 29 \%)$ [8].

$\mathrm{SOCl}_{2}(0.13 \mathrm{~mL}, 1.7 \mathrm{mmol})$ was added to a solution of $2-$ amino-5-nitrobenzoic acid $(0.062 \mathrm{~g}, 0.34 \mathrm{mmol})$ and NaphIsatin $(0.0083 \mathrm{~g}, 0.34 \mathrm{mmol})$ in dry pyridine $(20 \mathrm{~mL})$. The resulting mixture was refluxed for $1 \mathrm{~h}$ and then poured into ice water. The reaction mixture was extracted with dichloromethane, dried over anhydrous magnesium sulfate, and concentrated under vacuum to afford the crude product. Column chromatography on silica gel with dichloromethane as the eluent yielded pure Naph-T2NO as a purple solid $(0.018 \mathrm{~g}, 13 \%)$ [9].

A mixture of Naph-T2NO $2(0.015 \mathrm{~g}, 0.040 \mathrm{mmol})$ and $\mathrm{SnCl}_{2} \cdot 2 \mathrm{H}_{2} \mathrm{O}(0.048 \mathrm{~g}, 0.21 \mathrm{mmol})$ in tetrahydrofuran (THF, $18 \mathrm{~mL}$ ) was refluxed for $7 \mathrm{~h}$ under a flow of dry nitrogen. The reaction mixture was extracted with dichloromethane, dried over anhydrous magnesium sulfate, and concentrated under vacuum to afford the crude product. Column chromatography on silica gel with dichloromethane as the eluent yielded pure Naph-T2NH $\mathbf{N H}_{2}$ as a red solid $(0.0060 \mathrm{~g}$, 41\%) [10]. The HRMS of Naph-T2NH2 showed corresponding the molecular ion peaks, and the ${ }^{1} \mathrm{H}$ NMR spectrum confirmed that the desired compound was synthesized.

Naph-T2NH $2:{ }^{1} \mathrm{H}$ NMR $\left(500 \mathrm{MHz}\right.$, DMSO- $\left.d_{6}\right) \delta 6.45(1 \mathrm{H}$, $\left.\mathrm{s}, \mathrm{NH}_{2}\right), 7.12(1 \mathrm{H}, \mathrm{dd}, J=2.4 \mathrm{~Hz}, 8.7 \mathrm{~Hz}), 7.56(1 \mathrm{H}, \mathrm{d}, J=$ $2.4 \mathrm{~Hz}), 7.73-7.61(4 \mathrm{H}, \mathrm{m}), 8.20-8.12(3 \mathrm{H}, \mathrm{m}), 8.74(1 \mathrm{H}$, s), $9.92(1 \mathrm{H}, \mathrm{s})$; HRMS (ESI) $\mathrm{m} / \mathrm{z}(\mathrm{M}+\mathrm{H})$ calculated 364.1081, found 364.1023.

\section{RESULTS AND DISCUSSION}

In comparison with $\mathbf{T} 2 \mathbf{N H}_{2}$, Naph-T2NH2 exhibited red-shifted $\lambda_{\mathrm{a} \text {, max }}$ and $\lambda_{\mathrm{f}, \max }$ values $(476 \mathrm{~nm}$ and $604 \mathrm{~nm}$ in acetonitrile, respectively). The $\Phi_{\mathrm{f}}$ values of Naph-T2NH were significantly lower than those of $\mathbf{T} 2 \mathbf{N H}_{2}(0.0019$ and 0.56 in acetonitrile, respectively) [11]. The molecular structures of Naph-T2NH2 and $\mathbf{T} 2 \mathbf{N H}_{2}$ were calculated using density functional theory (DFT) [12]. The electron densities of the corresponding highest occupied molecular orbital (HOMO) and lowest unoccupied molecular orbital (LUMO) surfaces of Naph-T2NH2 and $\mathbf{T} 2 \mathbf{N H}_{2}$ are shown in Fig. 2.

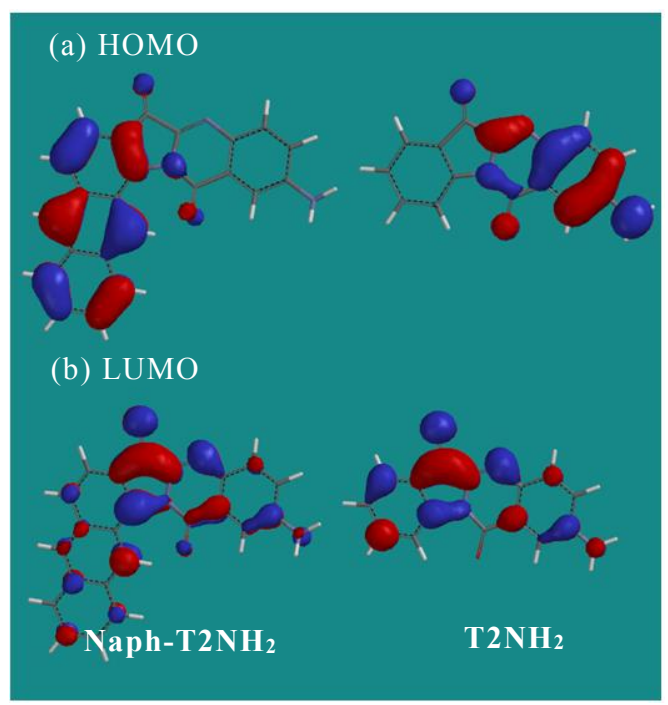

Figure 2 (a) Highest occupied molecular orbital (HOMO) and (b) Lowest unoccupied molecular orbital (LUMO) surfaces of Naph-T2NH2 and $\mathbf{T} 2 \mathbf{N H}_{2}$ according to DFT calculations.

The strong fluorescence of $\mathbf{T} \mathbf{2} \mathbf{N H}_{\mathbf{2}}$ can be attributed to the influence of intramolecular charge transfer (ICT) between the carbonyl group of the five-membered ring and the amino group [5]. Therefore, in $\mathbf{T} \mathbf{2} \mathbf{N H}_{2}$, the electrons are localized on the amino group in the HOMO and on the carbonyl group of the five-membered ring in the LUMO. This is also true for the electrons in the LUMO of NaphT2NH2. However, the electrons in the HOMO of Naph$\mathbf{T} 2 \mathbf{N H}_{2}$ are localized on the anthracene ring. This difference in electron distribution in the HOMO could be the reason for the low $\Phi_{\mathrm{f}}$ values of Naph-T2NH2. That is, the fluorescence of Naph-T2NH2 does not have ICT characteristics. The internal conversion or the intersystem crossing could be accelerated by the difference in electron distribution in the HOMO which are localized on the anthracene ring of Naph-T2NH2.

When $\mathrm{Mg}^{2+}, \mathrm{Ca}^{2+}, \mathrm{Ba}^{2+}, \mathrm{Co}^{2+}, \mathrm{Ag}^{+}, \mathrm{Zn}^{2+}$, and $\mathrm{Cd}^{2+}$ were individually added to the solution, the shape and intensity of the absorption spectra did not change, and the fluorescence spectra changed only slightly. Figure 3 a shows the absorption and fluorescence spectra of Naph-T2 $\mathbf{N H}_{2}$ with and without $\mathrm{Ag}^{+}$as a typical example. Slight changes in the fluorescence spectra were most likely due to collision quenching between Naph-T2NH $\mathbf{N H}_{2}$ and the metal ions.

The addition of $\mathrm{Fe}^{2+}, \mathrm{Fe}^{3+}, \mathrm{Ni}^{2+}, \mathrm{Cu}^{2+}, \mathrm{Hg}^{2+}$, and $\mathrm{Pb}^{2+}$ to the acetonitrile solution of $\mathbf{N a p h}-\mathbf{T} 2 \mathbf{N H}_{2}$ resulted in decreased absorption at $476 \mathrm{~nm}$ and observation of isosbestic points. The changes in the absorption spectra of Naph-T2 $\mathrm{NH}_{2}$ in the presence of $\mathrm{Fe}^{2+}, \mathrm{Fe}^{3+}, \mathrm{Ni}^{2+}, \mathrm{Cu}^{2+}$, $\mathrm{Hg}^{2+}$, and $\mathrm{Pb}^{2+}$ suggested that $\mathrm{Fe}^{2+}, \mathrm{Fe}^{3+}, \mathrm{Ni}^{2+}, \mathrm{Cu}^{2+}, \mathrm{Hg}^{2+}$, and $\mathrm{Pb}^{2+}$ complexes were formed in the ground state. After individual addition of $\mathrm{Fe}^{2+}, \mathrm{Fe}^{3+}, \mathrm{Ni}^{2+}, \mathrm{Cu}^{2+}, \mathrm{Hg}^{2+}$, and $\mathrm{Pb}^{2+}$ to a solution of Naph-T2NH2, the fluorescence at 604 $\mathrm{nm}$ was quenched. Figures $3 \mathrm{~b}$ and $3 \mathrm{c}$ show the absorption and fluorescence spectra of Naph-T2 $\mathbf{N H}_{2}$ with and without $\mathrm{Hg}^{2+}$ and $\mathrm{Pb}^{2+}$, respectively, as typical examples. The fluorescence at $604 \mathrm{~nm}$ for the Naph-T2 $\mathbf{N H}_{2}-\mathrm{Hg}^{2+}$ 
(a)

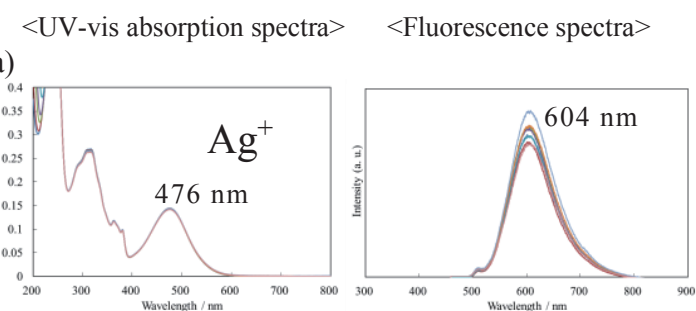

(b)

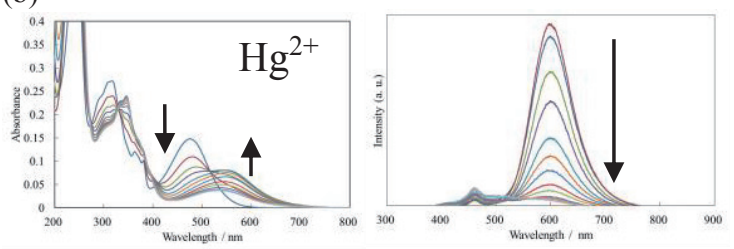

(c)

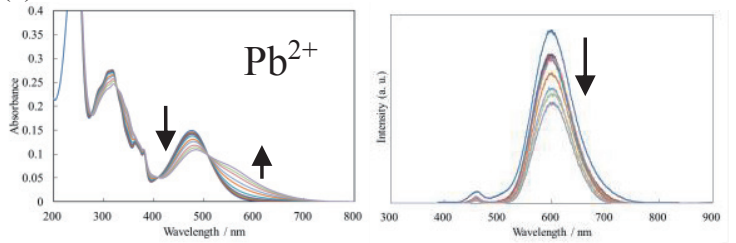

(d)

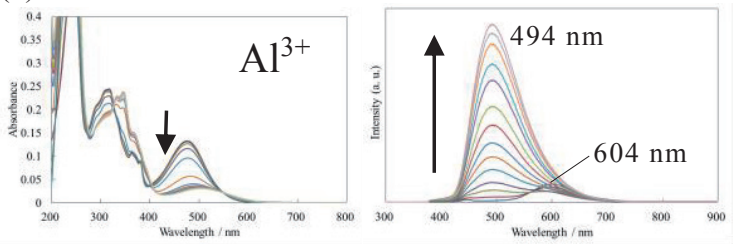

Figure 3 UV-vis absorption and florescence spectra of Naph-T2NH2 with (a) $\mathrm{Ag}^{+}$, (b) $\mathrm{Hg}^{+}$, (c) $\mathrm{Pb}^{2+}$, and (d) $\mathrm{Al}^{3+}$ in acetonitrile: [Naph-T2NH 2 ] $=10 \mu \mathrm{M}, \mathrm{Ag}^{+}, \mathrm{Hg}^{+}, \mathrm{Pb}^{2+}$, and $\mathrm{Al}^{3+}=0-1000$ equiv.

complex almost completely disappeared, while that of the Naph-T2 $\mathbf{N H}_{2}-\mathrm{Pb}^{2+}$ complex decreased by one third. The addition of $\mathrm{Al}^{3+}$ to the acetonitrile solution of Naph-T2NH resulted in a decrease in the absorption at $476 \mathrm{~nm}$, along with observation of isosbestic points, as shown in Fig. 3d (left). The change in the absorption spectraof Naph-T2NH in the presence of $\mathrm{Al}^{3+}$ also suggested that the $\mathrm{Al}^{3+}$ complex was formed in the ground state. After addition of $\mathrm{Al}^{3+}$ to a solution of Naph-T2NH2, the fluorescence at $604 \mathrm{~nm}$ slightly decreased and the fluorescence at $494 \mathrm{~nm}$ significantly enhanced, as shown in Fig. 3d (right). Fluorescence quenching occurs as a result of contamination by impurities, which leads to inaccurate results. Therefore, a fluorescence "emission" chemosensor, such as Naph$\mathbf{T} 2 \mathrm{NH}_{2}$, for $\mathrm{Al}^{3+}$ is important. These results show that Naph-T2 $\mathbf{N H}_{2}$ is a potential fluorescent chemosensor candidate for $\mathrm{Al}^{3+}$.

\section{CONCLUSION}

The detection of $\mathrm{Al}^{3+}$ is of great interest due to its potential toxicity and widespread presence [13]. Naph-T2NH 2 was synthesized as a fluorescent chemosensor for $\mathrm{Al}^{3+}$. We investigated the metal ion recognition of Naph-T2NH2 through individual addition of $\mathrm{Mg}^{2+}, \mathrm{Ca}^{2+}, \mathrm{Ba}^{2+}, \mathrm{Fe}^{2+}, \mathrm{Fe}^{3+}, \mathrm{Co}^{2+}, \mathrm{Ni}^{2+}, \mathrm{Cu}^{2+}, \mathrm{Ag}^{+}, \mathrm{Zn}^{2+}$, $\mathrm{Cd}^{2+}, \mathrm{Hg}^{2+}, \mathrm{Al}^{3+}$, and $\mathrm{Pb}^{2+}$ in an acetonitrile solution. When
$\mathrm{Mg}^{2+}, \mathrm{Ca}^{2+}, \mathrm{Ba}^{2+}, \mathrm{Co}^{2+}, \mathrm{Ag}^{+}, \mathrm{Zn}^{2+}$, and $\mathrm{Cd}^{2+}$ were individually added to the solution, the shape and intensity of the fluorescence spectra did not change. Conversely, when $\mathrm{Fe}^{2+}, \mathrm{Fe}^{3+}, \mathrm{Ni}^{2+}, \mathrm{Cu}^{2+}, \mathrm{Hg}^{2+}$ and $\mathrm{Pb}^{2+}$ were individually added to the solution, the fluorescence at 604 $\mathrm{nm}$ was quenched. However, the fluorescence at $494 \mathrm{~nm}$ increased significantly upon addition of $\mathrm{Al}^{3+}$. Thus, Naph$\mathbf{T} 2 \mathbf{N H}_{2}$ is well suited for use as a fluorescent chemosensor for $\mathrm{Al}^{3+}$.

\section{ACKNOWLEGMENTS}

This work was supported by JSPS KAKENHI Grant Number 25410137.

\section{REFERENCES}

[1] A. Witt and J. Bergman, Curr. Org. Chem., 7, 659-677 (2003).

[2] L. A. Mitscher, W. C. Wong, T. De Meulenere, J. Sulko, and S. Drake, Heterocycles, 15, 1017-1021 (1981).

[3] J. Kawakami, N. Matsushima, Y. Ogawa, H. Kakinami, A. Nakane, H. Kitahara, M. Nagaki, and S. Ito, Trans. Mater. Res. Soc. Japan, 36, 603-606 (2011).

[4] J. Kawakami, Tryptanthrin Derivatives, Patent No. 5448046, Japan, (Jan. 10, 2014).

[5] J. Kawakami, H. Kawaguchi, K. Kikuchi, A. Yamaya, S. Ito, and H. Kitahara, Trans. Mater. Res. Soc. Japan, 38, 123-125 (2013).

[6] J. Kawakami, A. Soma, K. Kikuchi, Y. Kikuchi, S. Ito, H. Kitahara, Anal. Sci., 30, 949-954 (2014).

[7] K. König, J. Microscopy, 200, 83-104 (2000).

[8] K. C. Rice, B. J. Boone, A. B. Rubin, and T. J. Rauls, J. Med. Chem., 19, 887-892 (1976).

[9] J. L. Liang, S. Park, Y. Kwon, and Y. Jahng, Bioorg. Med. Chem., 20, 4962-4967 (2012).

[10] F. D. Bellamy and K. Ou, Tetrahedron Lett., 25, 839842 (1984).

[11] The $\Phi_{\mathrm{f}}$ values were determined at room temperature relative to the absolute $\Phi_{\mathrm{f}}$ of 2 -( $N, N$-dimethyl)amino tryptanthrin in dichloromethane $\left(\Phi_{\mathrm{f}}=0.89\right)$ using solutions of matched absorbance $\left(0.1 \mathrm{~L} \mathrm{~mol}^{-1} \mathrm{~cm}^{-1}\right)$ at the excitation wavelength.

[12] Density functional theory calculations at the B3LYP/6$31 \mathrm{G}^{*}$ level were performed using the SPARTAN ' 10 software package (Wavefunction Inc., Irvine, CA, 2000). [13] J. L. Ren, J. Zang. J. Q. Luo, X. K. Pei, and Z. X. Jiang, Analyst, 126, 698-702 (2001).

(Received September 17, 2015; Accepted October 13, 2015) 